\title{
Isolated adductor myocysticercosis in a 6-year-old girl
}

\author{
Shahid Akhtar Siddiqui, Rajesh Kumar Yadav, Manisha Maurya, Anubha Shrivastava
}

Department of Pediatrics, Sarojini Naidu Children Hospital, Moti Lal Nehru Medical College, Allahabad, Uttar Pradesh, India

\section{Correspondence to} Dr Shahid Akhtar Siddiqui, sha.akht@yahoo.com

Accepted 18 September 2017

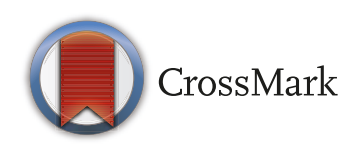

To cite: Siddiqui $S A$ Yadav RK, Maurya M, et al. BMJ Case Rep Published Online First: [please include Day Month Year]. doi:10.1136/bcr-2017222167

\section{DESCRIPTION}

A 6-year-old girl presented with asymptomatic right thigh swelling over medial aspect for 6 weeks. Examination revealed a $5 \mathrm{~cm} \times 4 \mathrm{~cm}$, non-tender, mobile swelling, not fixed to the skin or underlying structures. The rest of the examination was within normal limits. There was no history of seizures, headache or ophthalmic complaints. Ultrasonography of the right thigh revealed a well-defined cystic lesion measuring $11.5 \mathrm{~cm} \times 4.3 \mathrm{~cm}$ seen in the adductor muscle of the thigh with eccentric echogenic focus within (figure 1). No perilesional oedema was seen. Stool examination was negative for Taenia solium eggs. Serological testing could not be done due to affordability issues. A diagnosis of vesicular stage of isolated adductor myocysticercosis was made. Neuroimaging and ophthalmic
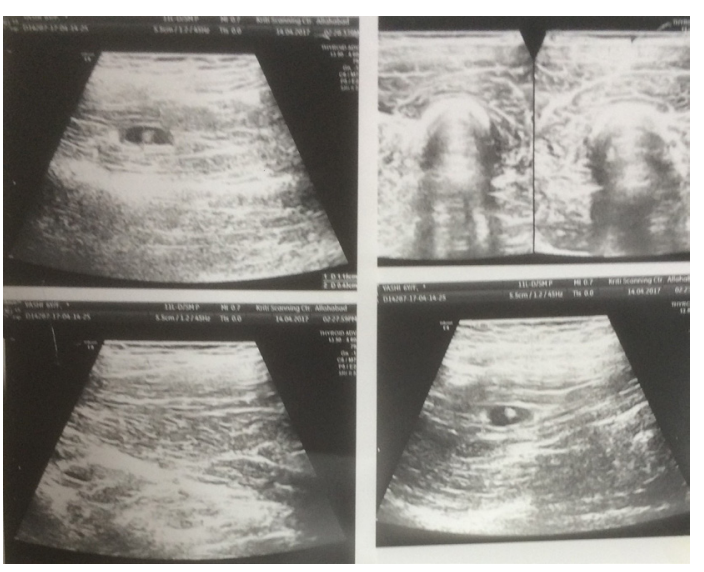

Figure 1 Showing well-defined cystic lesion with eccentric echogenic focus in adductor muscle of thigh.

\section{Learning points}

- Myocysticercosis is a parasitic disease caused by larval form of Taenia solium in tropics.

- Larvae may involve any organ system but mostly detected in the brain, eyes and muscles.

- A thorough search with neuroimaging and ophthalmic assessment should be done for central nervous system involvement as isolated myocysticercosis is unusual and rare.

assessment were unremarkable. Patient was treated with oral albendazole as an outpatient basis and had uneventful recovery at 1 month of follow-up with thigh swelling got completely resolved. However, we could not repeat an ultrasonography a few months later as she was lost to follow-up.

Occurrence of myocysticercosis caused by larval form of T. solium is not uncommon in developing countries like India. It may involve any organ system but mostly detected in the brain, eyes and muscles. A thorough search should be made for central nervous system involvement as isolated myocysticercosis is unusual and rare.

Contributors SAS: Followed up the case and wrote the manuscript. RKY: Worked up the case and prepared the final manuscript. MM, AS: Critical revision of the final manuscript. All the authors approved the final version of manuscript.

\section{Competing interests None declared.}

\section{Patient consent Obtained.}

Provenance and peer review Not commissioned; externally peer reviewed.

(c) BMJ Publishing Group Ltd (unless otherwise stated in the text of the article) 2017. All rights reserved. No commercial use is permitted unless otherwise expressly granted.

Copyright 2017 BMJ Publishing Group. All rights reserved. For permission to reuse any of this content visit http://group.bmj.com/group/rights-licensing/permissions.

BMJ Case Report Fellows may re-use this article for personal use and teaching without any further permission.

Become a Fellow of BMJ Case Reports today and you can:

- Submit as many cases as you like

- Enjoy fast sympathetic peer review and rapid publication of accepted articles

- Access all the published articles

- Re-use any of the published material for personal use and teaching without further permission

For information on Institutional Fellowships contact consortiasales@bmjgroup.com

Visit casereports.bmj.com for more articles like this and to become a Fellow 